\title{
Sposoby wizualizacji sygnałów ultradźwiękowych do wykrywania niezgodności w połączeniach zgrzewanych łukiem wirującym
}

\author{
The visualization of ultrasonic signals \\ and inspection of defects \\ in Magnetically Impelled Arc Butt welded elements
}

\section{Streszczenie}

Badania nieniszczące i testy funkcjonalne stanowią integralną część procesu produkcyjnego podzespołów i komponentów wykorzystywanych w przemyśle motoryzacyjnym. Półosie i wały napędowe zgrzewane łukiem wirującym (MIAB), będące elementami przeniesienia napędu są częściami, które podlegając ciągłym obciążeniom dynamicznym, muszą spełniać szczególnie wysokie kryteria jakościowe. Obecnie badania te polegają na kontroli parametrów procesu i badaniach niszczących (w tym badaniach metalograficznych i testach funkcjonalnych - zgniatanie, skręcanie, test płatkowy). W artykule przedstawiono nowatorską i innowacyjną w branży motoryzacyjnej, obejmującej producentów półosi i wałów napędowych nieniszczącą, ultradźwiękową metodę kontroli jakości połączeń zgrzewanych łukiem wirującym. Omówiono podstawowe rodzaje prezentacji sygnałów ultradźwiękowych oraz sposoby ich interpretacji. Szczególny nacisk położono na przedstawienie możliwości i funkcjonalności opracowanej autorskiej aplikacji, umożliwiającej wizualizację i akwizycję sygnałów ultradźwiękowych rejestrowanych podczas zautomatyzowanego badania zgrzein wykonanych metodą MIAB.

Słowa kluczowe: badania ultradźwiękowe; zgrzewanie łukiem wirującym; elementy przeniesienia napędu

\section{Abstract}

Non-destructive testing and functional tests are an integral part of the manufacturing process of components and constructions used in the automotive industry. The drive and transmission shafts joined by Magnetically Impelled Arc Butt (MIAB) welding process, continuously work under constant dynamic loads and must meet particularly high quality criteria. Currently, these tests involve the control of process parameters and destructive tests (including metallographic and functional tests - crushing, twisting, petal test). The article presents an innovative in the automotive industry, including transmission driveshaft manufacturers, non-destructive, ultrasonic quality control methods of MIAB joints. The basic types of presentation of ultrasonic signals are discussed as well as how they are interpreted. Particular emphasis has been placed on the presentation of the capabilities and functionality of the developed application, which enables the visualization and acquisition of ultrasonic signals recorded during automated MIAB weld tests.

Keywords: ultrasonic testing; Magnetic Impelled Arc Butt welding; transmission elements

\section{Wstęp}

Zastosowanie badań ultradźwiękowych do kontroli jakości podzespołów mających udział w produkcji pojazdów samo-

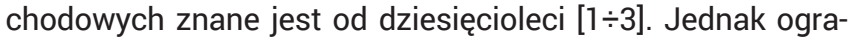
niczenia w postaci bardzo małych grubości ścianek powodują, że ich wykorzystanie $w$ badaniach jakości spoin i zgrzein elementów o grubościach poniżej $3 \mathrm{~mm}$ było bardzo ograni-

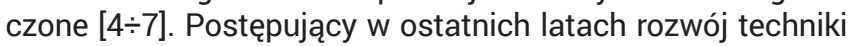

umożliwia wytworzenie przetworników o częstotliwościach znacznie przewyższających $10 \mathrm{MHz}$ i szerokości impulsu nadawczego wielokrotnie krótszego niż czas potrzebny na jego przejście przez element cienkościenny, dlatego aplikacje do badania połączeń o grubościach od 0,6 mm są coraz częściej spotykane np. w kontroli jakości połączeń zgrzewanych, złączy klejowych i pomiarach grubości warstwy zahartowanej.

Mgr inż. Agnieszka Bicz - Przedsiębiorstwo Badawczo-Produkcyjne OPTEL Spółka z o.o., dr inż. Marcin Korzeniowski, dr inż. Tomasz Piwowarczyk, dr inż. Paweł Sokołowski - Politechnika Wrocławska.

Autor korespondencyjny/Corresponding author: marcin.korzeniowski@pwr.edu.pl 
Technologia zgrzewania łukiem wirującym, pomimo tego, że znana od lat 50. XX wieku dopiero w ostatnich kilku latach zdobyła uznanie i znalazła zastosowanie w produkcji elementów przeniesienia napędu dla przemysłu samochodowego [8:9]. Obecność na rynku tej metody spajania wymusza na producentach półosi i wałów napędowych zapewnienia wymaganej aspektami bezpieczeństwa dostatecznej jakości, która kontrolowana powinna być już na etapie produkcji. Uniwersalne defektoskopy ultradźwiękowe, głowice i dostępne na rynku rozwiązania stacjonarne np. skanery i mikroskopy akustyczne, ze względu na specyfikę procesu zgrzewania łukiem wirującym, jak również zróżnicowaną i skomplikowaną geometrię detalu (rys. 1) utrudniają przeprowadzenie wiarygodnych badań metodą ultradźwiękową.
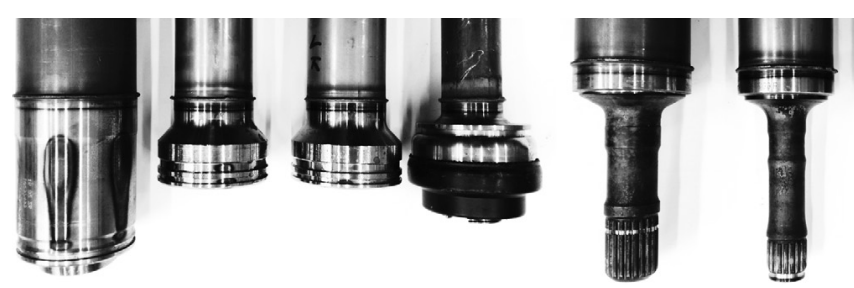

Rys. 1. Widok przykładowych komponentów zgrzewanych łukiem wirującym

Fig. 1. The MIAB welded drive shafts components

Do dodatkowych trudności zaliczyć należy zakrzywioną (w postaci walca) powierzchnię, długość elementu (dochodzącą do $1750 \mathrm{~mm}$ ) oraz obecność wypływki na powierzchni zgrzeiny. Wymienione aspekty, z równoczesnym zapotrzebowaniem odbiorców na elementy niezawodne, wytwarzane z zachowaniem najwyższych standardów jakości wymusiły konieczność kontroli na możliwie wczesnym etapie produkcji. Budowa stanowiska poprzedzona była nie tylko wnikliwą analizą zarówno geometrii, procesu produkcji, dotychczasowej kontroli jakości i niezgodności występujących w złączach, ale przede wszystkim aspektami związanymi z prawami akustyki geometrycznej, obejmującej zagadnienia związane z propagacją fali w ośrodku i opracowaniem dedykowanego przetwornika z ogniskowaniem wiązki. Obiektywny, powtarzalny i szybki (trwający kilka sekund) pomiar jest możliwy jedynie w przypadku automatyzacji procesu badania. Z tego względu zdecydowano się na opracowanie stanowiska, które wykorzystuje metodę immersyjną, wykorzystującą najczęściej środowisko wodne (lub inny roztwór, np. $\mathrm{z}$ inhibitorem korozji) do zapewnienia sprzężenia akustycznego pomiędzy przetwornikiem ultradźwiękowym a badanym materiałem. W przeciwieństwie do najczęściej stosowanego rozwiązania, jakim jest zanurzenie badanego detalu w zbiorniku z cieczą, opracowane stanowisko wykorzystuje specjalnie zaprojektowaną dyszę (rys. 2), w którą zamocowany jest przetwornik ultradźwiękowy. Do dyszy, doprowadzony jest strumień cieczy, który stanowi wymagane sprzężenie akustyczne.

Obecność wypływki na powierzchni zgrzeiny implikuje ograniczone zastosowanie fali podłużnej, padającej pod kątem $90^{\circ} \mathrm{w}$ stosunku do powierzchni badanej. Nieregularność wypływki powoduje rozpraszanie fali na jej powierzchni, co wyklucza zastosowanie tej metodologii badawczej. Z tego względu zdecydowano się na wykorzystanie zjawisk fizyko-akustycznych, głównie transformacji fali podłużnej na falę podpowierzchniową (ang. sub-surface, quasi lateral wave) na granicy ośrodków.

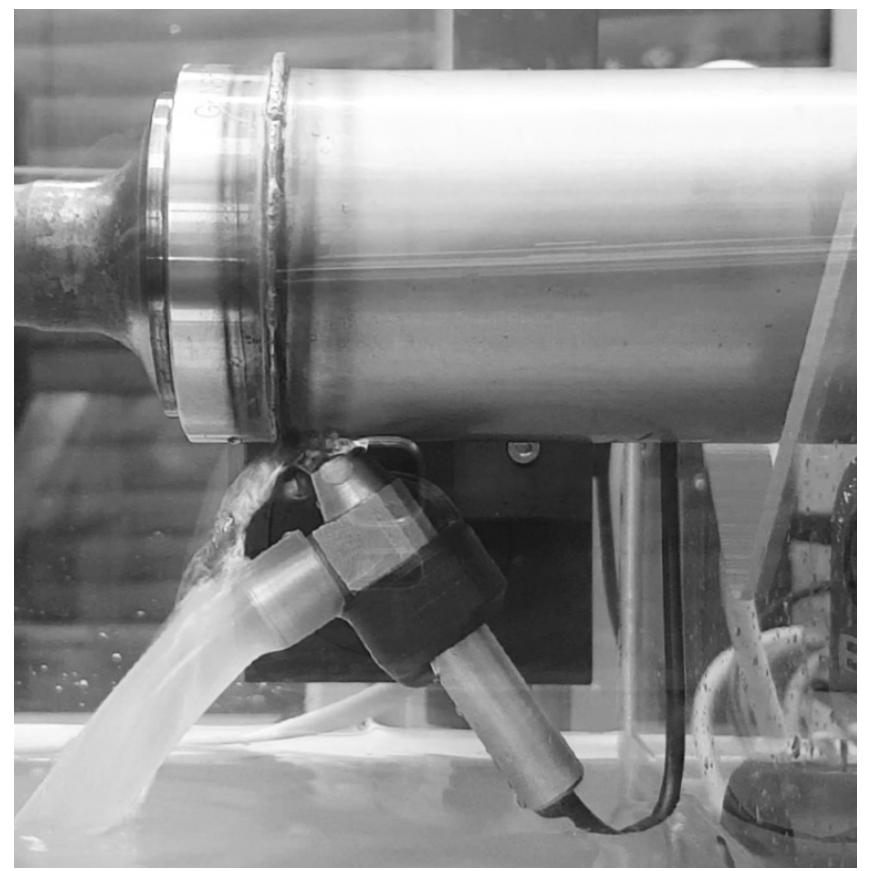

Rys. 2. Widok dyszy z zamocowanym przetwornikiem ultradźwiękowym i doprowadzaną cieczą sprzęgającą

Fig. 2. The view of nozzle and ultrasonic transducer - the integrated feeding of coupling liquid for UT testing

\section{Sposoby prezentacji sygnałów ultradźwiękowych}

Podczas badania wał napędowy jest obracany przez rolki napędzane silnikiem elektrycznym. W tym samym czasie unieruchomiony, ustawiony pod kątem $31,5^{\circ} \mathrm{w}$ stosunku do powierzchni rury ogniskujący przetwornik ultradźwiękowy o częstotliwości środkowej $10 \mathrm{MHz}$, ognisku w odległości $21 \mathrm{~mm}$, wielkości ogniska 0,4 mm i długości ogniska $6,1 \mathrm{~mm}$ rejestruje sygnał pochodzący od potencjalnych niezgodności, które pojawiały się w interesującym obszarze tj. w zgrzeinie MIAB. Należy podkreślić, że kąt $31,5^{\circ}$ został dobrany na podstawie rozważań teoretycznych i obliczeń szeroko opisanych w artykule [10]. Gwarantuje on powstanie w ściance rury ultradźwiękowej fali podpowierzchniowej, która została wykorzystana do badań.

W każdym punkcie pomiarowym emitowany jest krótki impuls dźwiękowy, a następnie mierzona jest odpowiedź napięciowa przetwornika piezoelektrycznego pod wpływem powracających fal odbitych na granicach ośrodków. Przetworzony programowo przebieg amplitudy fali w czasie określany jest jako A-scan (od ang. amplitude). Przykład typowej prezentacji A-scan uzyskiwanej podczas badań ultradźwiękowych wałów na opracowanym stanowisku zaprezentowano na rysunku 3.

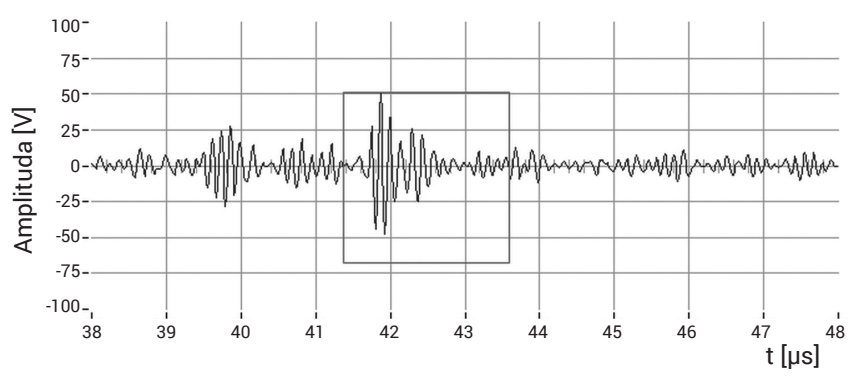

Rys. 3. Przykładowa prezentacja A-scan rejestrowana podczas badań na opracowanym stanowisku

Fig. 3. The exemplary A-scan obtained by using in-house UT system 
Z uwagi na dynamikę systemu pomiarowego i mnogość punktów pomiarowych analiza dużej ilości prezentacji A-scan może być uciążliwa. Z tego względu bardziej użyteczną w analizie jest prezentacja B-Scan (ang. brightness), stanowiąca zbiór prezentacji typu $A$, zarejestrowanych wzdłuż linii obrotu wału, zrzutowanych na płaszczyznę. B-Scan ma najczęściej formę mapy dwuwymiarowej w skali szarości, w której oś odciętych odpowiada przesunięciu kątowemu lub numerowi punktu pomiarowego na obwodzie wału. Odcień w skali szarości odpowiada amplitudzie zarejestrowanej fali.

\section{Aplikacja i interfejs użytkownika}

Interfejs aplikacji został zaprojektowany w sposób umożliwiający operatorowi, niezaznajomionemu dogłębnie w fizykę fal ultradźwiękowych łatwą i intuicyjną obsługę, ograniczającą się głównie do czynności mechanicznych tj. ustawienie wału na rolkach oraz przyciśnięcie przycisku "Start". Zmiana parametrów fal ultradźwiękowych, zakresu obserwacji, prędkości obrotowej i kryteriów oceny możliwa jest poprzez uruchomienie panelu administracyjnego, niedostępnego dla operatora.

Opracowana i zintegrowana z układem mechanicznym aplikacja składa się z okna głównego (rys. 4), w którym znajdują się podstawowe parametry akwizycji sygnałów ultradźwiękowych oraz panelu administracyjnego, umożliwiające zarządzanie programami, zaawansowanymi parametrami akwizycji, ustawieniami mechanicznymi systemu, a także sposobem prezentacji danych pomiarowych.
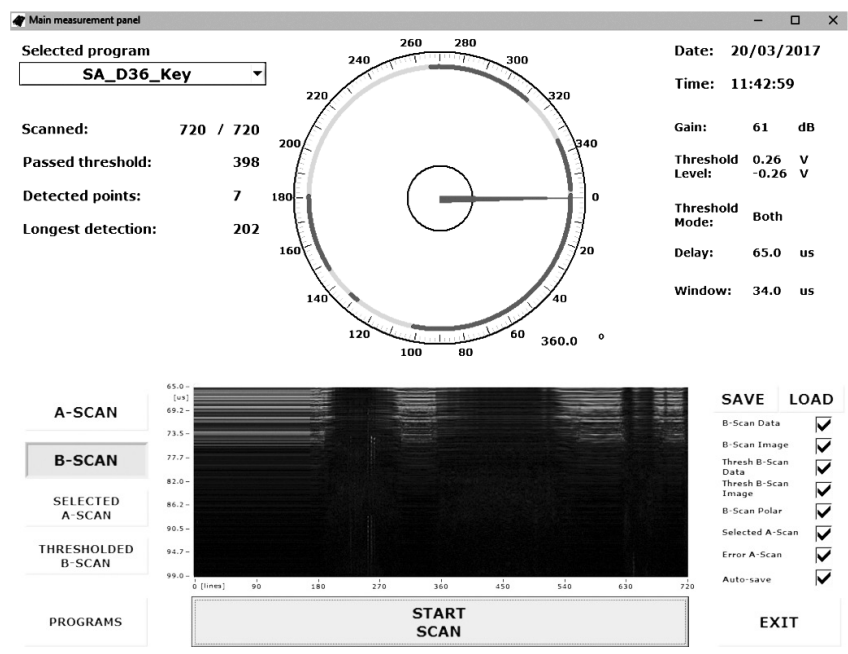

Rys. 4. Widok okna głównego aplikacji do sterowania i wizualizacji wyników pomiaru półosi zgrzewanych łukiem wirującym

Fig. 4. The screenshot presenting the application enabling the control of UT testing and data post-processing

Na rysunku 4 przedstawiono okno główne aplikacji sterującej stanowiskiem, umożliwiającej rejestrację, zapis i wizualizację wyników pomiaru.

Okno główne programu składa się z przycisków związanych ze sterowaniem układu mechanicznego ("Start Scan"), przycisków umożliwiających wizualizację sygnału ultradźwiękowego w wybranej formie ("A-scan”, "B-scan”, „Selected A-scan”, „Thresholded B-scan") oraz przycisku „Exit”, który powoduje wyjście z aplikacji. Lista rozwijana "Selected program" daje użytkownikowi możliwość wyboru rodzaju konkretnego wału napędowego (zdefiniowanego wcześniej w oknie panelu administracyjnego), bez konieczności wprowadzania informacji o jego średnicy, długości i rodzaju elementu, którym jest zakończony (wał krótki, przegub). Przyciski "Save" i "Load" służą do zapisu i odczytu wybranych poprzez zaznaczenie pól typu checkbox prezentacji sygnałów ultradźwiękowych.

W środkowej części okna aplikacji znajduje się wizualizacja obwodu zgrzeiny wykreślona w układzie biegunowym. Na podstawie założonych wcześniej kryteriów oceny, opracowane oprogramowanie w sposób automatyczny dokonuje oceny jakości zgrzeiny, wizualizując obszary spełniające zadane kryteria kolorem zielonym. Miejsca, oznaczone kolorem czerwonym ilustrują obszary poza ograniczonym przez administratora progiem czułości. Z punktu widzenia operatora określenie 2-stanowego poziomu jakości (dobry - zły), bez konieczności analizy genezy pojawienia się wskazania interpretowanego przez oprogramowanie jako niezgodność jest niezwykle korzystne, powoduje, że pomiar jest szybki, łatwy i nie wymaga od operatora kwalifikacji i specjalistycznego przeszkolenia w zakresie zaawansowanych technik ultradźwiękowych.

Dobór kryteriów oceny dla każdego badanego elementu odbywa się w sposób empiryczny i eksperymentalny. Jest to podyktowane różną prędkością dźwięku w badanych elementach, zależną od rodzaju stali, z której wykonany jest wał, różną grubością ścianki oraz zróżnicowaną geometrią wypływki na powierzchni zgrzeiny.

Jak wspomniano w rozważaniach teoretycznych, podstawową wizualizacją sygnału ultradźwiękowego jest tzw. A-scan, tj. przedstawienie amplitudy sygnału w funkcji czasu (lub uwzględniając prędkość dźwięku w ośrodku - jednostce odległości). Aktywowanie kontrolki „A-scan” powoduje pojawienie się $\mathrm{w}$ dolnej części aplikacji okna z prezentacją A-scan, wizualizującą aktualnie rejestrowany sygnał z przetwornika ultradźwiękowego. Przedstawiona na rysunku 5 przykładowa prezentacja A-scan obejmuje czas przejścia sygnału ultradźwiękowego w zakresie znacznie przekraczającym interesujący obszar pomiarowy. Znajdują się na nim sygnały odpowiadające odbiciom od końca wału, w tym również odbicia wielokrotne. Zakres pomiarowy, który jest analizowany przez oprogramowanie dla omawianego systemu ogranicza się wyłącznie do miejsca, w którym znajduje się zgrzeina. Z tego powodu algorytm analizuje wyłącznie sygnał ultradźwiękowy, który znajduje się w obszarze ograniczonym bramką pomiarową, ograniczającą sygnał w dziedzinie czasu (szerokość "L", rys. 5). Wszystkie punkty poza zaznaczonym obszarem nie są poddawane analizie. Wysokość bramki (wysokość "H", rys. 5) stanowi próg, na podstawie którego podejmowana jest decyzja "dobry - zły".

Po przekroczeniu przez sygnał ultradźwiękowy progu ograniczonego wysokością bramki, obszar na wizualizacji odpowiadającej obwodowi wału, w którym przekroczony został założony próg, oznaczany jest kolorem czerwonym, co informuje operatora o nie spełnionych założonych kryteriach i może być podstawą do dyskwalifikacji wyrobu.

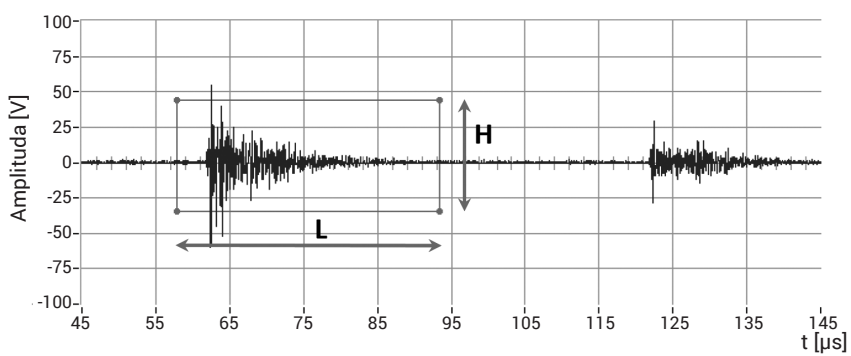

Rys. 5. Prezentacja A-scan sygnału ultradźwiękowego podczas przejścia fali przez wał napędowy

Fig. 5. The A-scan presenting the ultrasonic signal during the propagation in drive shaft 
W przeciwnym wypadku miejsce na obwodzie oznaczone jest kolorem zielonym (rys. 4). W górnej części okna głównego aplikacji, po lewej stronie znajdują się podstawowe informacje statystyczne o przeprowadzonym pomiarze:

- „Scanned" - liczba punktów pomiarowych zbadanych na elemencie / całkowita liczba punktów pomiarowych,

- „Passed threshold" - prezentuje liczbę punktów pomiarowych, dla których wyniki przekroczyły zadaną bramkę pomiarową (wysokość "H", rys. 5),

- "Detected points" - przedstawia liczbę wykrytych niezgodności (punktowych lub większych),

- "Longest detection" - przedstawia wielkość największej wykrytej wady (w postaci liczby punktów pomiarowych).

Do szczegółowej analizy zarejestrowanego w trakcie pomiaru sygnału ultradźwiękowego, wykorzystać można prezentację B-scan, czyli zbiór prezentacji A-scan przedstawiony np. w skali szarości (lub innej palecie barw), na której oś $x$ reprezentuje punkt pomiarowy na powierzchni wału, oś y - czas przejścia fali ultradźwiękowej (lub po uwzględnieniu prędkości dźwięku w materiale - odległość), a skala szarości amplitudę fali ultradźwiękowej.

$\mathrm{Na}$ rysunku 6a przedstawiono przykładową prezentację B-scan zarejestrowaną podczas badania wałów z wykonanymi 6 niezgodnościami wprowadzonymi sztucznie oraz dla wybranego jednego punktu na powierzchni wału (biała linia na prezentacji B-scan) prezentację A-scan (rys. 6b).

a)

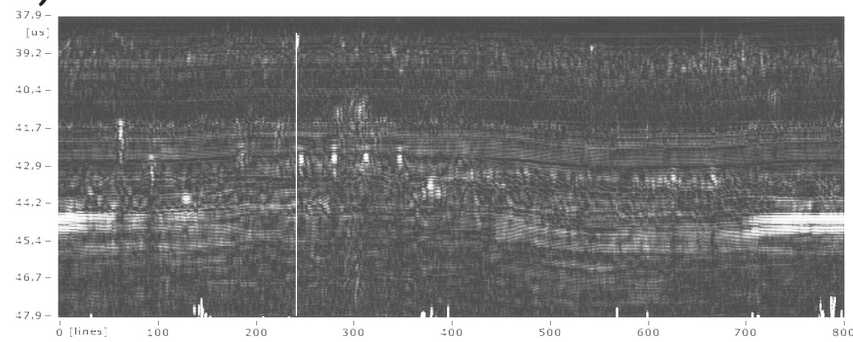

b)

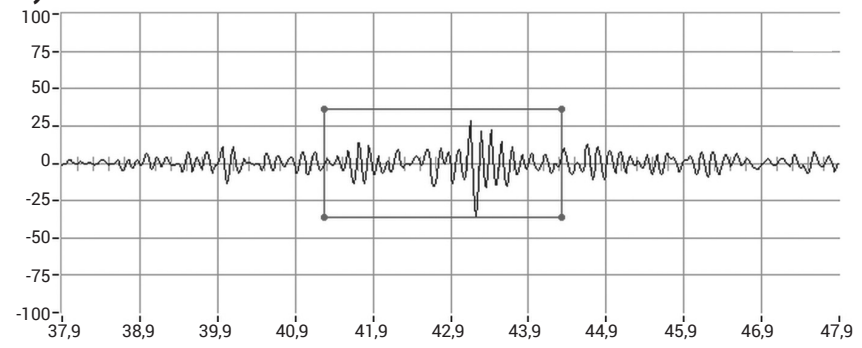

Rys. 6. Przykładowa prezentacja B-scan z uwidocznionymi 6 niezgodnościami na obwodzie zgrzeiny (a) oraz prezentacja A-scan w wybranym punkcie na powierzchni wału (b)

Fig. 6. The presentation of six welding defects on the exemplary B-scan (a) and A-scan data in a selected point on the drive shaft surface (b)

Zaawansowane parametry akwizycji sygnału ultradźwiękowego, takie jak na przykład: opóźnienie, wzmocnienie, offset, zmiana prędkości obrotowej podczas pomiaru, ilość punktów pomiarowych przypadających na jeden obrót wału (rozdzielczość), jest możliwa do ustawienia w panelu administracyjnym (rys. 7), do którego dostęp mają wyłącznie osoby uprawnione.

\section{Testy aplikacji}

Test aplikacji polegał na zmianie wysokości bramki pomiarowej w oknie prezentacji A-scan, a następnie obserwacji zmian barw (skali szarości) odpowiadających kwalifikacji dobry - zły. Na rysunku $8 a \div 8$ c przedstawiono przykładowe

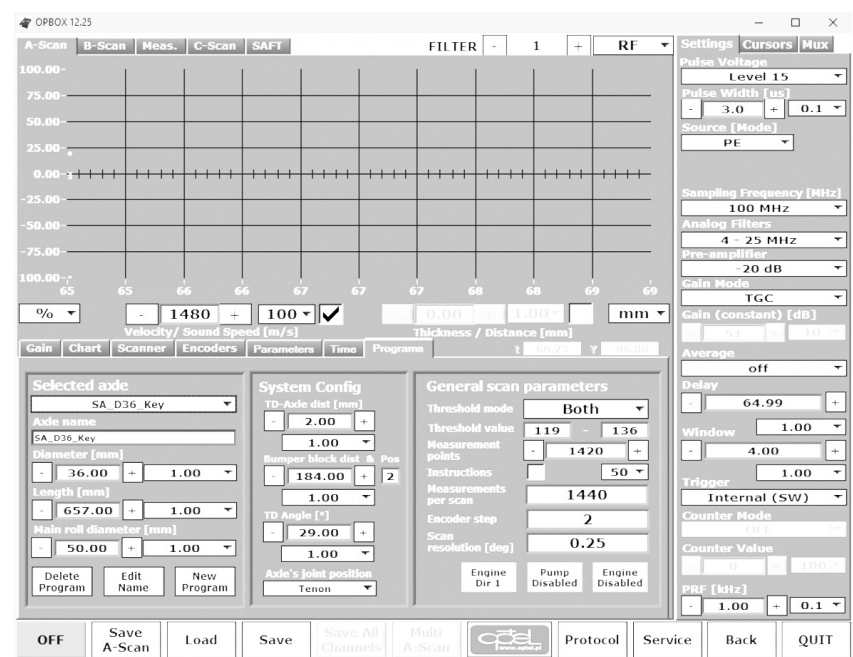

Rys. 7. Widok panelu administracyjnego opracowanej aplikacji do pomiarów ultradźwiękowych półosi i wałów napędowych

Fig. 7. The admin panel interface of the in-house made application enabling the quality examination of the tubular transmission elements

prezentacje A-scan z bramką pomiarową na wysokości ok. $75 \%, 20 \%$ i wysokości pełnej skali osi pionowej ekranu.

Z uwagi na to, że wysokość bramki odpowiada za próg binearyzacji sygnału ultradźwiękowego jej zmiana powoduje zmianę czułości układu pomiarowego, który każdorazowo po przekroczeniu ustawionego zakresu automatycznie dokonuje oceny spoiny jako „zły”. Na rysunku 9 przedstawiono schematycznie obwód zgrzeiny wraz z interpretacją graficzną dla 3 poziomów bramki pomiarowej (75\%, 20\% i 5\% skali ekranu). Kolor czerwony oznacza przekroczenie progu zadanego przez bramkę pomiarową.

a)

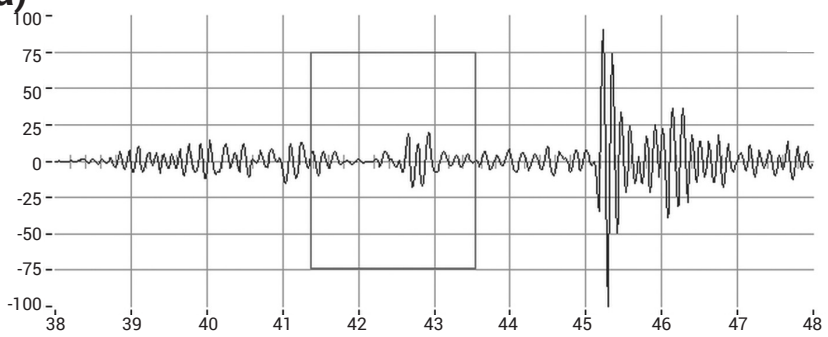

b)

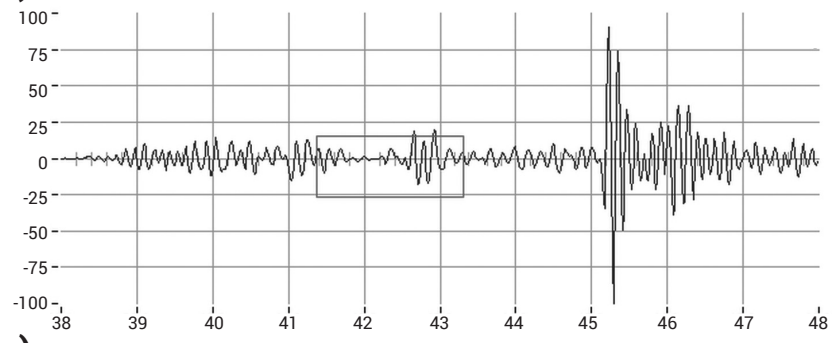

c)

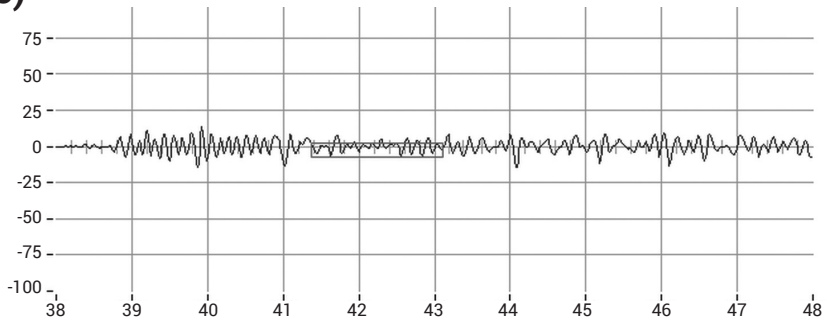

Rys. 8. Widok prezentacji A-scan z bramką pomiarową na poziomie: $75 \%$ skali ekranu (a), 20\% skali ekranu (b) i $5 \%$ skali ekranu (c)

Fig. 8. The presentation of the A-scan when the threshold gate is equal to: $75 \%$ (a), $20 \%$ (b) and $5 \%$ of the screen scale 
a)

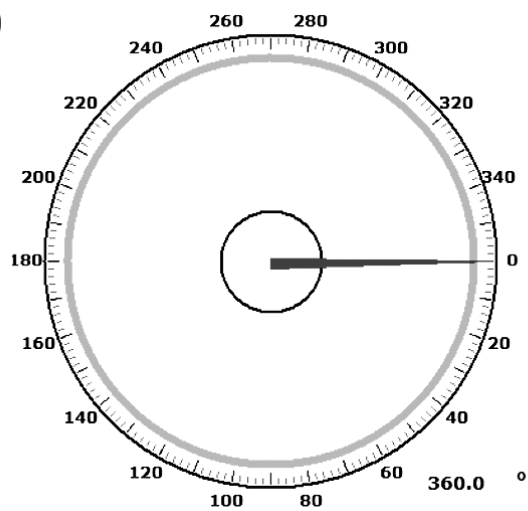

b)

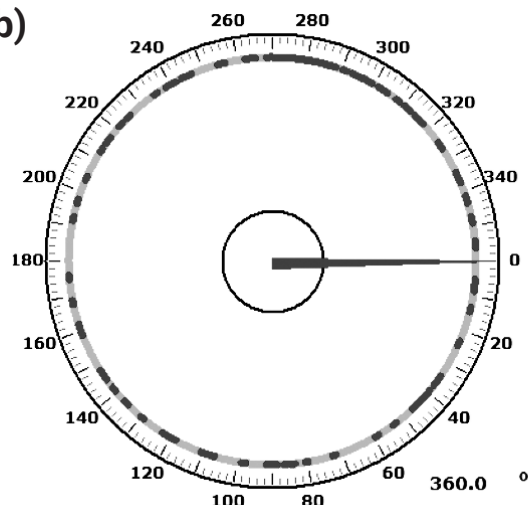

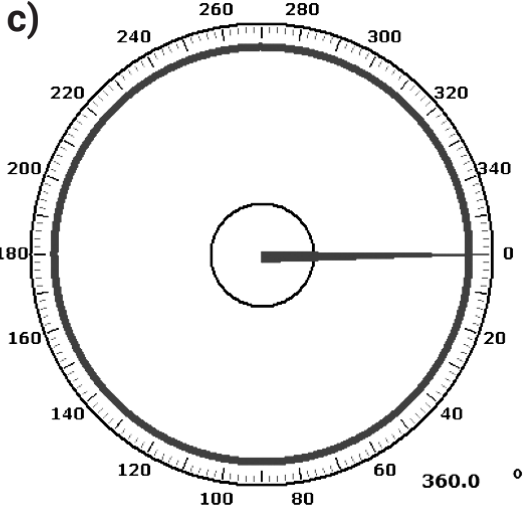

Rys. 9. Interpretacja graficzna wyników analizy ultradźwiękowej na obwodzie zgrzeiny MIAB dla 3 poziomów bramki pomiarowej: $75 \%$ skali ekranu (a), 20\% skali ekranu (b) i 5\% skali ekranu (c)

Fig. 9. The graphical interpretation of the UT testing when the threshold gate is equal to: $75 \%$ (a), $20 \%$ (b) and $5 \%$ of the screen scale (c)

\section{Wnioski}

Zgrzewanie łukiem wirującym jest technologią spajania, wykorzystywaną do wytwarzania elementów przeniesienia napędu od zaledwie kilku lat. Z uwagi na niewielką grubość ścianek łączonych komponentów (poniżej $3 \mathrm{~mm}$ ) dostępne na rynku systemy ultradźwiękowe nie mogły zostać zastosowane do badań potencjalnych niezgodności występujących w tym procesie. W ramach prac badawczych realizowanych przez Konsorcjum naukowo-przemysłowe, składające się z firm GKN Driveline Oleśnica sp. z o.o. i Optel sp. z o.o. oraz Katedry Materiałoznawstwa, Wytrzymałości i Spawalnictwa Politechniki Wrocławskiej opracowano dedykowane, autorskie stanowisko, które umożliwia ocenę jakości złączy zgrzewanych łukiem wirującym. Testy wstępne stanowiska obejmujące część mechaniczną, układ sterowania oraz działanie aplikacji, potwierdziły skuteczność metody ultradźwiękowej do oceny jakości połączeń zgrzewanych łukiem wirującym w elementach przeniesienia napędu. Zaimplementowane programowo funkcjonalności, polegające na szerokiej gamie możliwości zmian parametrów zarówno akwizycji sygnału ultradźwiękowego, jak również wizualizacji (pełny A-scan, A-scan wybranego - ograniczonego bramką zakresu, B-scan) stwarzają możliwości wiarygodnej i obiektywnej oceny jakości wytworzonych komponentów.

\section{Artykuł powstał w ramach projektu pt. „Kryteria i metodyka określania jakości złączy zgrzewanych łukiem wirującym” współfinansowanym przez Narodowe Centrum Badań i Rozwoju w ramach III Programu Badań Stosowanych.}

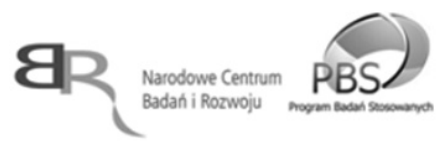

\section{Literatura}

[1] R. J. Brown: Non-destructive testing in industry, Non-Destructive Testing, vol. 6, nr 2, pp. 81-85, Apr. 1973

[2] Praca zbiorowa pod redakcją I. A. E. Agency: Non-destructive testing: A guidebook for industrial management and quality control personnel International Atomic Energy Agency, IAEA-TCS-9, 1999.

[3] W. Roye: Ultrasonic Testing of Spot Welds in the Automotive Industry, Krautkrämer GmbH \& Co. oHG, nr SD 298, Listopad 1999.

[4] M. Stachurski: Ultrasonic testing of thin-walled joints (3-7 $\mathrm{mm}$ in thickness), Advances in Manufacturing Science and Technology, vol. 29, no. 2, pp. 93-102, 2005

[5] M. Stachurski: Badania ultradźwiękowe połączeń cienkościennych (o grubości 3-7 mm), Biuletyn Instytutu Spawalnictwa w Gliwicach, vol. 49, nr 2, s. 57-61, 2005

[6] A. Bicz, W. Bicz, M. Korzeniowski, T. Piwowarczyk, A. Ambroziak: Ultrasonic Tests in the Analysis of the Quality of Tubular Welded Elements, Biuletyn Instytutu Spawalnictwa, nr 5, 2016.
[7] J. Wiklund, U. Idermark: Ultrasonic transducers for testing of thin-walled tubes, Materialpruefung, vol. 18, pp. 280-284, 1976.

[8] T. Piwowarczyk, A. Małachowska, P. Sokołowski: Tendencje rozwojowe zgrzewania łukiem wirującym w aspekcie zastosowań w przemyśle motoryzacyjnym, Przegląd Spawalnictwa, vol. 85, nr 6, 2013.

[9] V. S. Kachinskiy, V. G. Krivenko, V. Y. Ignatenko: Magnetically Impelled Arc Butt Welding of Hollow and Solid Parts, Weld World, vol. 46, nr 7-8, pp. 49-56, 2002.

[10] P. Kustroń, M. Korzeniowski, T. Piwowarczyk, P. Sokołowski: Application of Immersion Ultrasonic Testing For Non-Contact Quality Evaluation of Magnetically Impelled Arc Butt Welded Drive Shafts of Motor Vehicles, Advances in Automobile Engineering, vol. 2017, 2017. 